\title{
HOW DO STUDENTS ASSESS THE SUSTAINABILITY OF THEIR UNIVERSITYP A COMPARISON BETWEEN DUTCH AND ROMANIAN STUDENTS FROM BUSINESS SGHOOLS
}

\author{
Florentin Popescu ${ }^{1}$, Tudor Edu ${ }^{2}$, Iliuţă Costel Negricea ${ }^{3}$, Răzvan Zaharia ${ }^{4}$ \\ and Rodica Milena Zaharia ${ }^{5^{*}}$ \\ ${ }^{1)}$ HAN University of Applied Sciences (Arnhem Business School), Netherlands \\ ${ }^{2) 3}$ Romanian American University, Romania \\ ${ }^{4) 5)}$ The Bucharest University of Economic Studies, Romania
}

Please cite this article as:

Popescu, F., Edu, T., Negricea, I.C., Zaharia, R. and Zaharia, R.M., 2020. How Do Students Assess the Sustainability of Their University? A Comparison between Dutch and Romanian Students from Business Schools. Amfiteatru Economic, 22(54), pp. 411-431.

DOI: $10.24818 / \mathrm{EA} / 2020 / 54 / 411$

\section{Article History}

Received: 30 December 2019

Revised: 8 February 2020

Accepted: 24 March 2020

\begin{abstract}
This article is exploratory in its essence and aims to analyse the sustainability of universities in the case of three higher education institutions: one university from the Netherlands and two universities from Romania. The main focus is on the awareness of the sustainable university concept among students and on the perception students have about their university: do they consider their university as being a sustainable one? Why? Do they consider they are educated to act as future sustainable business persons? There is a growing interest in researching students' perceptions on the sustainability of universities. Students are the key stakeholders; they represent the future business people, employees, managers or entrepreneurs, responsible for sustainable development. Therefore, universities have to build a "sustainable mindset" for their graduates.

This research related to students' perception on sustainable university has two phases. The first one involved a secondary data analysis, based on the online information provided by the universities, in order to assess the sustainability of these universities considering the adapted Deming spiral (planning, operating, reporting and innovating). The second phase involved a qualitative research among students from these three universities, based on focus groups, about the awareness of the sustainable university concept, how they perceive their university from the sustainability point of view and how prepared they consider to be to act as future sustainable persons. Comparisons between universities are performed. The conclusions discuss possible solutions for universities to become more sustainable, and good practices that can be shared among universities are identified.
\end{abstract}

Keywords: sustainable university, sustainable development, students' opinion, Netherlands, Romania

JEL Classification: Q01, Q56, I29

* Corresponding author, Rodica Milena Zaharia-milena.zaharia@rei.ase.ro 


\section{Introduction}

The issue of sustainable university grew in importance in the last decade. The debate is a complex one. The society, in general, has increased expectation from universities: to be not only educators for sustainability, but to act as sustainable actors. Challenges brought by the sustainable development test universities in the way they are organised, in the curricula they deliver, in the manner they respond to the demands of young generation who is asking to be better informed and equipped to protect the environment and to support a sustainable society. The sustainable university becomes, thus, a vector of sustainable development, by redefining its mission and by reshaping the context in which it acts. The mission of the sustainable university (teaching, researching, and community involvement) has to be reinterpreting from a sustainable perspective: what educational principles have to be promoted in order to contribute to the promotion of sustainability for the society? How should these principles be delivered? Towards which domains should the research be oriented? How does the academic research contribute to a more sustainable economy and society? What about the relationship with the stakeholders for sustainability? What actions should university develop for the community in order to become an agent for sustainability? From the context point of view, a sustainable university promotes and acts, at a regional and global level, to reduce the negative effects on the economic, social and natural environment (for example, from the perspective of the use of the resources, to move to green energy, or, from the perspective of the results of the activity, to reduce waste, gas emissions, etc.) (Sonetti, Lombardi and Chelleri, 2016). Therefore, a sustainable university is that one which is a leader in the society through actions for supporting natural ecosystem and through education for generations suitable for sustainability (Lukman and Glavič, 2007).

This article brings into discussion the concept of sustainable university from the students' perspective. The purpose of this research is to investigate students' perceptions on the sustainability of their university, on an example of three higher education institutions: one from the Netherlands and two from Romania. The research objectives are to investigate the awareness of the sustainable university concept among students, to identify how students assess their universities in terms of sustainability, and to find out the opinion students have about their education for sustainable development: do they consider they are educated to act as future sustainable business persons? The research presents a comparison between the perceptions of students coming from these three universities and involves a qualitative research based on focus groups.

The present study is a qualitative, exploratory research. The selection criteria for these universities have been determined by the commitment towards sustainability these universities expressed, by the institutional partnership existed between these entities, by the opportunity of a research grant FSS Shanghai at Arnhem Business School in 2019 offered to one of the authors of this paper on a topic related to sustainable development and, finally, by a lasting cooperation existed between the authors of this paper in teaching and research. Also, the profile of the universities is similar in order to have students exposed to similar curricula (social sciences). Focus groups involved students for business master programs. Students have been selected using convenience sampling, based on free agreement and on guarantee of confidentiality of information. In qualitative research, apart from the quantitative one, convenience sampling is largely accepted and used, mostly when the access to studied population is difficult ( $\mathrm{Li}$, et al., 2012; Brewis, 2014; Kivunja, 2015; Zaharia and Zaharia, 2017). Prior to this, a secondary data analysis based on online 
information provided by the universities on their websites was performed in order to determine the sustainable profile of the universities based on adapted Deming spiral (Lukman and Glavič, 2007). Students' perception on the sustainability of universities from different countries is still less investigated and these research results add to the existed empirical outcomes, contributing to a consolidation of the theoretical basis for sustainable university concept.

The paper starts with a literature review on the concept of sustainable university. The second section is devoted to the methodological aspects of the study. The third section analyses the sustainability profile of the universities. Data collected from the six focus groups organized among students from the three selected universities (two focus groups in each university) are discussed in the fourth part. The paper ends with conclusions, limits and further research and managerial implication of the results in terms of good practices that can be developed based on the paper findings.

\section{Literature review}

The concept of sustainable university grabs the attention mostly in the last two decades. Despite the fact that sustainability, in general, spreads in all areas, from ecology, to economy, science and technology, the academic setting is still in its infancy (Nejati and Nejati, 2013). (Note: It is not the purpose of this article to go into the literature that covers the term sustainability. However, this paper will relate sustainability with the term sustainable development, launched by the Brundtland Commission, in 1987, and refers to the sustainable development as being that kind of development that "ensures that it meets the needs of the present without compromising the ability of future generations to meet their own needs" (Assembly, 1987, p.16)).

As scholars underline, academics (faculty and university leaders) are still unaware about what strategies should be adopted for achieving sustainability, what principles should govern a sustainable university, what activities a sustainable university should perform, or how a university should collaborate with its stakeholder in order to become a promoter of sustainable development in the community (Van Weenen, 2000; Comm and Mathaisel, 2003; Waas, et al., 2011; Lozano, et al., 2013; Nejati and Nejati, 2013; Dabija, et al., 2017; Adams, Martin and Boom, 2018).

Among the first approaches that linked sustainability and university are 'education for sustainable development', 'education for sustainability or 'sustainability education' (Lukman and Glavič 2007, p.105). These terms are used interchangeably and they express, ultimately, the role education must have in offering knowledge about sustainable development, in shaping attitudes towards sustainability and in developing a behaviour to face the challenges sustainability launches. The most used term is Education for Sustainable Development (ESD), launched at the World Conference on Environment and Development, Rio de Janeiro (1992) (UNESCO, 2002). As UNESCO (2002, p.5) stated in a manifesto after 10 years from the introduction of the concept, "education for sustainable development became an emerging but dynamic concept that encompasses a new vision of education that seeks to empower people of all ages to assume responsibility for creating a sustainable future". 
However, many scholars consider that ESD is only a step in building a sustainable university. Teaching about sustainability should not be the only role assumed by universities. Universities must to contribute to the welfare of the planet through all their specific aspects: education, research, management and community involvement (Sterling, Maxey and Luna, 2013). This is not an easy task. Universities are a part of a complex and dynamic system, and influence and are influenced by other participants. Universities themselves are a multipart and inertial subsystem and, therefore, becoming sustainable involves more than adopting a few measures in some areas (like teaching about sustainability or promoting academic research towards topics related to sustainable development or environment protection). A sustainable university is a multistep construct, where the concern for sustainability is reflected in all stages: from mission and vision to strategies and policies (on teaching, research, community involvement, and university campuses) and then to creating networks, auditing, and continuing improvements (Velazquez, et al., 2006). A university that is sustainable has to plan, to implement, to assess, to report sustainable practices, to ensure consistency and coherence between the implementation method and the assessment and report tools (Amaral, Martins and Gouveia, 2015). Sustainability has to be a continuous improvement process, similar to Deming's spiral. W. Edwards Deming proposed a Plan-Do-Check-Act (PDCA) to monitor the improvement efforts. PDCA is a management philosophy considering that progress is a never ending process, achieved through small improvement steps (Velazquez, et al., 2006). The "Plan" stage is for assessing the state of the art and for identifying the vulnerable points, and what solution for solving the problem can be generated. The "Do" stage means to select the most appropriate solution. "Check" refers to verifying the consequences of the proposed solution on the desired result. "Act" involves the implementation of the solution in order to solve the problem. This is a never ending process as new challenges appear mostly when it comes to improve the sustainability of the institution (Velazquez, et al., 2006, p.817).

An important aspect that is insufficiently developed by the literature devoted to the analysis of the sustainability of universities is the stakeholders' perception, mainly the students' perception. There are insufficient studies that address students' perception on the sustainability of universities, despite the fact that students are the primary target of the education process and that the students represent the future leaders that should apply sustainable practices in the society (Kagawa, 2007; Emanuel and Adams, 2011; Martin, 2012; Nejati and Nejati, 2013; Dabija, et al., 2017). Comparative studies are even less encountered and those that involve students from developed countries versus developing countries are quite rare. Knowing students' opinion about the university sustainable practices is a critical source of information for decision makers. Investigating students' knowledge and attitudes towards sustainability is not only a matter of university's performance, but a way to promote sustainability through a more informed and proactive student engagement (Kagawa, 2007; Nejati and Nejati, 2013; Yuan and Zuo, 2013).

Most of the studies focus on students' perceptions about the curricula for sustainability (Kagawa, 2007; Lukman and Glavič, 2007; Sterling, Maxey and Luna, 2013; Nejati and Nejati, 2013). Students have exposure to disciplines that address various aspects of sustainability (sustainable development, environmental protection, etc.), and generally associate sustainable university with the sustainable development. However, the simple awareness of the importance of sustainability, although as first step, is not enough for a sustainable university. Just teaching students about sustainability as an intellectual concept is not enough, and there is a risk of failure in developing future responsible citizens 
(Martin, 2012). A sustainable university contributes to a sustainable society also through the way the career and professional goals of its graduates are in harmony with the sustainable goals of the society.

Research that had in their center the students' perception about university's sustainability, investigated, also, opinions on the campus sustainability or practices developed by a sustainable university (Lozano, 2006; Emanuel and Adams, 2011; Nejati and Nejati, 2013). Students are concerned about campus sustainability and environmental issues, in general, but creating a campus in harmony with the natural environment requires very large resources, often beyond the universities' own capabilities (Dabjia, et al., 2017). Sustainability practices must be understood and applied by all members of the academic community.

What is required from a sustainable university, from the students' perspective, is that it has not only to provide knowledge about sustainability or to build sustainability skills, but to offer a platform through which students can test and implement this knowledge and these skills. The more sustainable a university is, the more attractive it becomes for students. Sustainability can become an element of attracting the most involved, most inventive, most motivated students (Martin, 2012), just as it can use their energy to become proactive in promoting sustainability at the society level (Martin, 2012; Nejati and Nejati, 2013).

This article proposes a double comparison of sustainability of selected universities: firstly, against the accepted concept of sustainable development and secondly based on the perception of students. Are there differences or similarities between universities reflected in the students' opinion? Are there differences between what universities "say" on their websites and how students perceive their sustainability?

\section{Research methodology}

The research involved two phases. The first phase was a secondary data analysis. Based on the adapted Deming spiral, data collected from the universities' websites were considered in order to design the descriptive sustainability profile of the university from which the students were interviewed. The second phase involved focus groups with students in order to identify their perception on the sustainability of their university. Data were collected using the semistructured interview. This research involved six focus groups, two at each university. The target students were those from business schools, in order to have a stronger base for comparison. The participation of students in focus groups was based on their freely agreement. The aim was to ensure a group structure as diverse as possible from the socio-demographic and behavioral point of view. The students were informed that their participation in the focus group discussion is voluntary, that they can withdraw from the discussion whenever they wish, that their opinions are confidential and that the information will be used for the academic purposes only. They were also guaranteed anonymity of responses.

The focus groups were composed of 6 to 9 master students in each case, mainly gender balanced. All students were between 21 and 26 years of age. However, it was not the purpose of this study to have any comparisons in terms of age, gender, or other characteristics. For the Bucharest University of Economic Studies (BUES), the two focus groups consisted of students from the marketing master program. The first focus group had 6 students; the second one had 8 students. The focus groups from the Romanian American University (RAU) were composed also of students from marketing master program; the 
first one had 6 students, the second one had 7 students. The focus groups from the HAN University of Applied Sciences were drawn from students enrolled at the Arnhem Business School (ABS), International Business and Communication Management Studies, with 9 students in the first focus groups and 9 students in the second focus group.

The themes launched for focus group discussions derived from the research objectives (figure no.1):

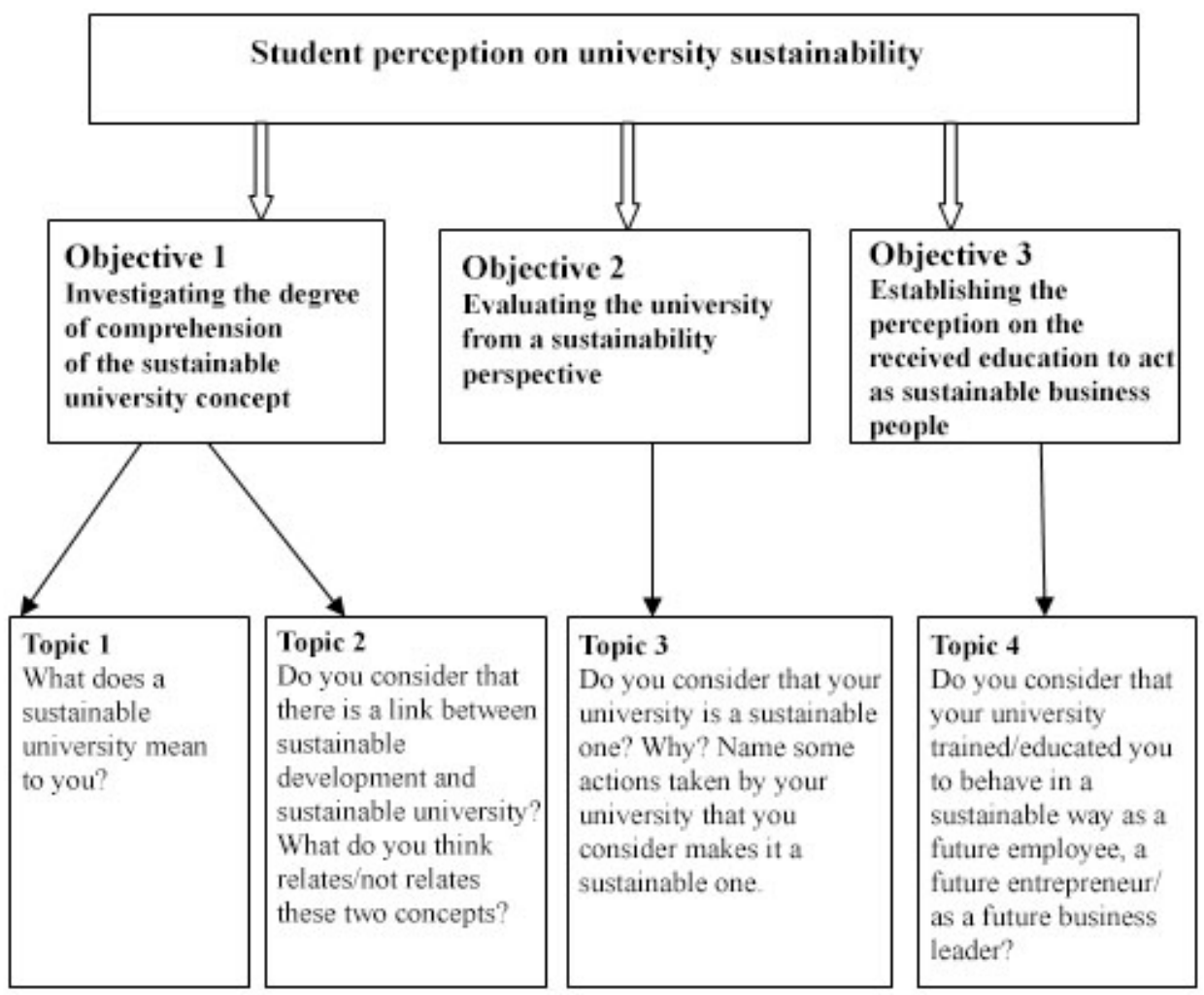

Figure no. 1: The Goal-Objectives-Topics relationship for focus group discussions

The answers were coded and those codes generated categories that were analysed. The coding was done using the "paper and pencil" approach (Björk and Kauppinen-Räisänen, 2012). Initially, Nvivo was considered, which is a very useful tool for large qualitative files (for example, in the study of Ríos-Martín, Folgado-Fernández, Palos-Sánchez, and Castejón-Jiménez, Nvivo was used to analyse over 500 PDF files and over 5000 comments) (Rios -Martin et al., 2020). As with the study of Björk and Kauppinen-Räisänen (2012), in this research, the narration was rather short, not determining a broad structuring of the data. Researchers compared their data and based on the evidence offered by the literature, the discussion section was elaborated. Recommendations were provided in the sense that some good practices emerged from this analysis. 


\section{Descriptive sustainable profile of the universities}

The first phase of the research was to analyse the way the three universities performed against criteria developed for a sustainable university, by searching the universities' websites and university official documents available online. This article proposes an analysis of the sustainability of university started from the concepts proposed by Velazquez et al. (2006), Lukman and Glavič (2007), Nejati and Nejati (2013), and Sterling, Maxey and Luna (2013). It is assumed that a sustainable university is that university that is committed towards sustainability by planning, operating, reporting and innovating on sustainable principles (adapted Deming spiral).

Planning on sustainable principles means that the university is engaged through its mission, vision and core value to contribute to sustainable development (Velazquez et al., 2006; Lukman and Glavič, 2007).

Operating means that sustainability is present in education, research, community involvement and campus organisation of the university (Velazquez et al. 2006).

Reporting on sustainability means that a university communicates to its stakeholders (internal and external) the commitment towards sustainability through reports or through the participation in sustainable networks (Velazquez et al., 2006; Lozano et al., 2013).

Innovating on sustainable principle means that the university is proactive, building sustainable networks, proposing new actions to achieve sustainability (Lukman and Glavič, 2007).

\section{HAN University of Applied Sciences (Arnhem Business School)}

HAN University of Applied Sciences is one of the 5 largest universities of applied sciences in the Netherlands and hosts over 30,000 students (2017). The two campuses of HAN University (Arnhem and Nijmegen) have programs in the technical, economic, health, sport, behaviour and society, and education areas. At the core of HAN University there are 4 faculties: Faculty of Education, Faculty of Health and Social Studies, Faculty of Business Management and Law, and Faculty of Engineering.

\section{Planning}

According to the "mission and values", the university is "committed to promoting and sharing knowledge and skills, and to making these available to a wider audience by: (i) providing superior quality education while adhering to a code of conscientious and responsible professional practice; (ii) striving towards sustainability in all that we undertake; (iii) ensuring that our employees act with personal integrity and social responsibility; (iv) embodying our core values of involvement, responsibility, ownership and professional identity; (v) working on the basis of honesty, trust, and clear, concise agreements" (HAN, 2019).

\section{Operating}

HAN (ABS) offers a large range of courses, and sustainability is part of the education provided to the students of all faculties. Societal needs (ex. sustainable energy) and realworld dilemmas are among the purposes of the education at HAN University. Education for sustainability is embedded in all courses. HAN University fosters the introduction of sustainability as a part of any report that students have to prepare, recognizing the importance that education has in order to shape the future behaviour of its graduates. 
Research at HAN University of Applied Sciences is multidisciplinary, practice-based and relates to themes from the professional world (i.e. "Smart cars", "Sustainable Electrical Energy Centre of Expertise") (HAN, 2019).

\section{Reporting}

HAN publishes an annual Report that has a part devoted to sustainability (HAN, 2019). The engagement towards sustainability started in 2007. From that moment, HAN University of Applied Sciences acted towards diverse plans, from improving the energy system, to waste management, from public purchasing based on sustainable principles, to certificate sustainable courses (HAN, 2018). Arnhem Business School is preparing the Ethics Responsibility and Sustainability Policy in order to receive EPAS accreditation. EPAS accreditation is the most thorough program accreditation system for business and/or management program. It is acknowledged worldwide by potential students, employers, clients and the media (EFEMED, 2019).

\section{Innovating}

HAN is a member of the Higher Education Sustainable Initiative (HESI), a partnership created under the auspices of the United Nations in 2012 in the run-up to the United Nations Conference on Sustainable Development (Rio+20) (UN, 2019). Different programmes from HAN University of Applied Sciences have Hobeon certificate for sustainable education (Chiodo, 2013; HAN, 2018). Higher Education Sustainable Initiative (HESI), a partnership between United Nations Department of Economic and Social Affairs, UNESCO, United Nations Environment, UN Global Compact's Principles for Responsible Management Education (PRME) Initiative, United Nations University (UNU), UNHABITAT, UNCTAD and UNITAR, created in 2012 in the run-up to the United Nations Conference on Sustainable Development (Rio+20) (UN, 2019).

\section{The Bucharest University of Economic Studies (BUES)}

BUES was established in 1913 and is a public university, the largest and the most prestigious economic university in Romania. In 2018, BUES had 12 faculties in the area of economics, business and public administration, over 22,000 students enrolled in 24 bachelor programmes (with courses provided in Romanian, English, French or German), 84 master programs, 10 study area for doctoral and postdoctoral studies (ASE, 2019, p. 9).

\section{Planning}

According to the University Charta, BUES is a public university that has, among fundamental principles (Art 3) "public accountability and social responsibility". No other reference towards sustainability is present in the University Charta (ASE, 2013). In the Strategy of the University (ASE, 2014), sustainability is also a general aspect related to a part of the university's mission and vision (BUES has to be a leader in education and research in order to contribute to a competitive and sustainable economy). There is no specific mention that the university made sustainability as a core focus of its activity.

\section{Operating}

In terms of education for sustainable development, many courses integrate at least the principles of sustainable development. There are, also, specific courses in sustainable 
development (ex. Marketing and Sustainable Development, Sustainable development strategies for food industry). BUES has many research projects that focus on aspects related to sustainable development, and organises conferences, symposiums, and summer schools on the topic of sustainable development. As a leading economic university, BUES has, also, numerous partnerships with the business environment and some of these partnerships are in the area of sustainability.

\section{Reporting}

Despite an active operating dimension of sustainability, there are no reports (or part of the reports) on sustainability. There is a comprehensive report delivered annually by the Rector of the university that reflects the activity of the university, as well as a Quality Assurance Report. All these reports provide detailed information related to the teaching activities (disciplines taught in all faculties and programs), research projects, conferences, workshops, symposiums, students' satisfaction about campus life. All those reports are missing in providing information devoted to sustainable practice the university follows (related, for example, to waste management or energy saving). Communication (internal and external) focusing on sustainability is missing.

\section{Innovating}

In terms of innovation in sustainability, there are no information on the university website about membership of alliances or associations for sustainability.

\section{Romanian American University (RAU)}

RAU is a private university from Romania, established in 1991. The university offers bachelor and master programmes in Romanian and English through its 7 faculties (in business, law, and physical education, sport and kinesiotherapy), enrolling approximately 3000 students (URA, 2019, p. 18).

\section{Planning}

RAU supports its mission, that of offering education and research at a high quality standard in a stimulating intellectual internal environment for students and academic body through a set of values, amongst which one can be assessed as touching sustainability grounds, that of being professionally, morally and socially responsible in its academic and research endeavours. Also, one of the strategies envisaged by the management is to be actively involved in projects focusing on social, economic and cultural development at regional and national levels through education, know-how and technology transfer.

\section{Operating}

The university website provides detailed information about the educational programs offered at bachelor and master levels, including those that contain information about sustainable development, "green" disciplines or social entrepreneurship. Information is also provided about the journals edited by the university and conferences organised with its support, but they are not specific to sustainable aspects. However, very little information can be found on the involvement in practice, with some exceptions, probably the most notable one being the strong ties with businesses in providing tailored academic programmes, but without a focus on sustainable aspects. Information about the centres 
hosted on campus is displayed on the website. The most notable ones are the Department of Asian Studies, Microsoft Innovation Center or IATA Authorized Training Center. Moreover, the courses taught by foreign academics and practitioners are widely covered, the university attempting to differentiate itself based on these courses. Information related to sustainable education, programmes or community involvement, however, are very few and lost among information that characterize a traditional university (Lozano et al., 2013), not a university that switch to sustainability.

\section{Reporting}

Comprehensive quality assurance annual reports can be downloaded from the website covering especially quality assurance strategies, procedures, structures and policies, procedures for initiating, monitoring and revising of educational programmes, procedures for appraising educational outcomes, procedures for student and academic body evaluation, accessibility of learning resources, information systems; public information transparency on educational programs (URA, 2019). The university does not publish a sustainability report or does not have a specific communication on the actions promoted towards sustainability.

\section{Innovation}

URA is not member of alliances or associations for sustainability or, at least, no information about this or about initiatives to launch actions related to sustainability is available on the university website.

\section{Discussions}

Based on the public information presented by the three universities, the level of sustainability differs among them. It may be considered that HAN University (ABS) is more oriented towards sustainability than the selected Romanian universities. Both BUES and RAU are traditional universities, concentrating their interest on providing education and performing research (BUES is part of the Consortium Universitaria, which brings together the top 5 advanced research universities from Romania). From the sustainability point of view, BUES and RAU are mainly adaptive towards sustainability especially (in the research and education areas) and reactive (in the area of community engagement). HAN (ABS) can be considered adaptive and proactive, in the sense that the research is adaptive and the curricula and community engagement are proactive.

Started form the proposed theoretical approaches, between the analysed universities there are similarities in the area of planning and mainly in the area of operating and differences in the area of reporting and innovating. The three universities include in their operating area courses and programmes dealing with sustainability. All of them organise events related to sustainability and all of them are involved in research focused on sustainability. Only HAN (ABS) reports on sustainability and manifests some initiatives towards sustainability.

Based on these results, we expected a different level of awareness related to the concept of sustainable university coming from the students, as well as a different appreciation towards the sustainability of their own university. The focus groups prompted interesting findings. In order to capture the essence of the research output, the results are presented in a structured and comparative approach (see figures no. 2, 34 and 5) 


\subsection{Students' perceptions on the sustainability of their university}

a) What does a sustainable university mean to you?

The findings showed a difference in the awareness of the concept between the Dutch and the Romanian students. The awareness of the concept of sustainable university is quite low among the Romanian students. The groups from BUES were confused about the question. The RAU groups were also confused; the answers ranging from "No idea" from most group members to "a sustainable university is that one that teaches about sustainable development" or "is taking care about the ecological balance". Some of the BUES respondents answered with another question "is this about how the university takes care of the environment?" Others said that they had never heard about "sustainable university". To substantiate this, it is worth mentioning that in the case of RAU's groups, the number of students not knowing anything about the concept surpassed the number of those that attempted to explain it. The Romanian students (from both universities) mentioned that they had never thought of their university from a sustainable point of view ("Hhmm, I have never thought of this before...sustainable university? It is pretty much like sustainable development, isn't it?"). And it was quite difficult for them not only to shape the concept of sustainable university, in general, but to mention against what criteria they should appreciate if a university might be or not considered a sustainable one. Some of the students considered that a sustainable university is "a university that takes care of its infrastructure". There were 4 students at the BUES that related sustainability to "environment protection", "fighting against plastic waste" or "reducing pollution". Students from HAN University Arnhem Business School are more aware about the concept itself, and more familiarized with the characteristics of a sustainable university: in the vision of ABS students, sustainable university means: renewable energy sources (solar panels, green energy), recycling, waste management (less waste, responsible consumption in the idea that if you consume less, then you will produce less waste) less meat consumption, no plastic. Other comments were even more interesting: "A sustainable university is that one capable to continue to operate for a long term", or "a sustainable university is that one capable to inspire students to develop their intelligence and views without damaging the immediate environment, and pushing them in a certain direction - a sustainable one". However, both Dutch and Romanian students relate, firstly, the sustainable university concept to environmental issues (waste and energy: lower energy consumption, recycling). The Romanian students (from BUES and RAU) concentrate their awareness almost entirely on the few aspects of the environmental protection (as lower the energy consumption or recycling). The Dutch students were richer in their answers, mentioning that a sustainable university is concerned about the "environmental footprint", "is looking for renewable energy sources", "limits the gas emission" or "promotes ecological behaviour among its students and faculties". Students from the ABS mentioned, also, other characteristics that define a sustainable university: a sustainable university has to take into consideration "the need of their stakeholders" and "makes a difference among other universities through its impact in the community". These findings support the evidence from the literature showing that students, in general, relate sustainability more with environmental aspects rather than economic and social elements (Zeegers and Clark, 2014; Nejati and Nejati, 2013). A synthesis of the discussion on this theme is presented in the figure no. 2 


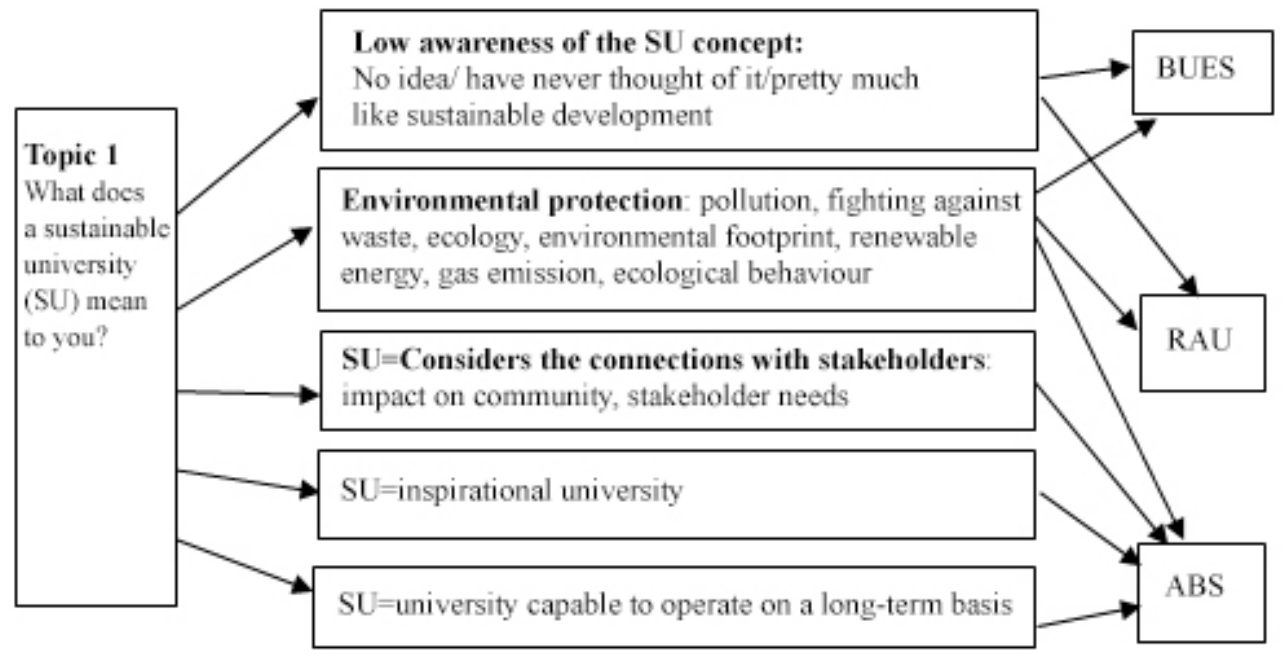

Figure no. 2: What does a sustainable university (SU) mean to you?

b) Do you consider that there is a link between sustainable development and sustainable university? What do you think relates/not relates these two concepts?

The direct relationship between sustainable university and sustainable development seems to be a very clear one for both Dutch and Romanian students. When asked to sustain the definitive "yes", the same pattern as for the first question was followed. There is a strong association made by the students from the Netherlands and Romania between environment protection and sustainable development. In all six focus groups students mentioned that "environmental protection" or "fighting against climate change" were the key elements that linked the two concepts (sustainable development and sustainable university). Almost all of the Romanian students "insisted" on the main idea that "sustainable development needs sustainable universities" or that "you cannot have sustainable development without sustainable universities". Only a few Romanian students (BUES) mentioned that "fighting against poverty" was an element that connected the two concepts. The Dutch students provided more elaborated answers, mentioning that the relationship between sustainable development and sustainable university was given by the "waste and recycling", "energy use", "tackle the climate change", "education about sustainability", "innovation", "green operations", "sustainable actions, "being adaptive" or the social dimension, that was common for both sustainable development and sustainable university ("looking at the community needs should be the concern for both sustainable development and sustainable university", "concerning about social exclusion") or the "international dimension" of the sustainable development that is "a part of the sustainable university". Some of them (4) mentioned that the link was "sustainability" itself! An interesting couple of answers discussed the relationship between the sustainable development and sustainable university: "sustainable development is in place, sustainable university should follow", "a university should always keep up with sustainable development", "a sustainable university should use sustainable development to try and to implement/improve sustainable resources". Summarizing, the link between sustainable development and sustainable university is presented in figure no.3. 


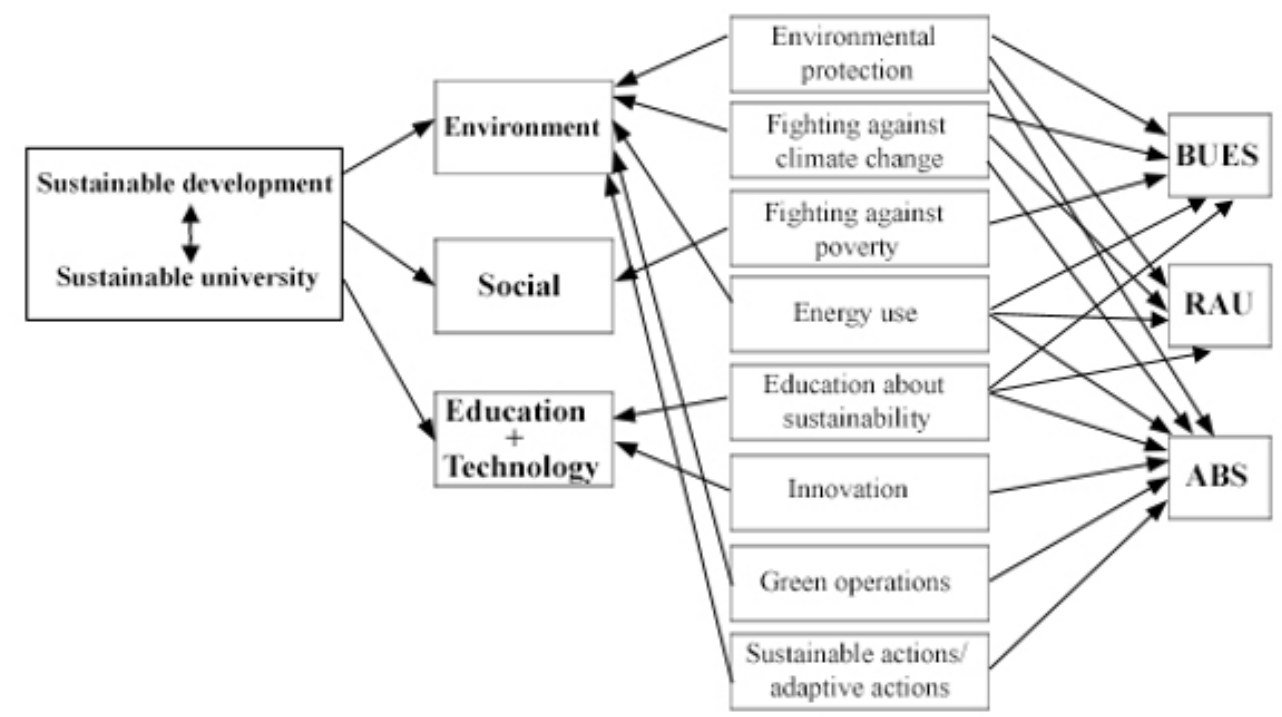

Figure no. 3: The relationship between Sustainable Development and Sustainable University

c) Do you consider that your university is a sustainable one? Why? Name some actions taken by your university that you consider makes it a sustainable one.

The answers of students regarding the actions pursued by a sustainable university were assessed against the actions characterizing a sustainable university defined by Nejati \& Nejati (2013, p.106): sustainable commitment and monitoring, land use and planning, waste and energy, community outreach. As a result of the interviews conducted, we added to the sustainable commitment and monitoring characteristics a group of actions: "courses about sustainable development", "students and staff involvement in sustainable actions", "internal and external communication about sustainability". The perception about the sustainability of their own university looks even more different in the eyes of the Dutch students comparing to the Romanian one. Often the answer "I don't know" came out from the discussions in the groups from both Romanian universities. Romanian students mentioned actions from the waste and energy areas, like "Recycling bins across campus" (from BUES and RAU), "awareness campaign about reducing the energy consumption" (from BUES and RAU), as well from the sustainable commitment: "we have subjects focusing on sustainable development" (from BUES and RAU), "I heard that we, as university, supported campaigns on cleaning the filed or planting some trees...I think" (BUES), "we had workshops with guest speakers on sustainable business practices" (RAU). From the area of community outreach some actions were mentioned: "I know that there are some partnerships with NGOs for helping elders and children (BUES); some actions towards the community" (from BUES and RAU). Students from the Arnhem Business School (ABS) are more aware about their university's actions towards sustainability. They specified: "courses about sustainability, "vegan products distribution in cafeteria", "organising cleaning actions around the campus", "using biodegradable dishes". 
One important difference is that students from ABS use the expression "I have been involved in/ I have attended..." more often than the Romanian students. This shows that the sustainable practices used by the Romanian universities are more chaotic and more declarative; there is not a clear avenue towards sustainability in the policies/strategies of the Romanian universities. Despite the fact that Romanian universities organise many events, conferences, symposiums and many research projects related to sustainability are in place in these universities, students are not enough involved and they are not aware about the essence of these actions. One student from BUES commented when the moderators asked about these scientific endeavours developed by the university: "just another event, without any practical end". Universities from Romania do not have a good communication policy on sustainability and their sustainable practices are lost among other activities performed by them. Comparatively, ABS is more focused on these aspects and has a clearer communication strategy towards sustainability. Students are better informed; they can assess the sustainability of their university more specifically and they are more exigent with their university when it comes to sustainability. In the view of ABS students, HAN University (ABS) is rather a university that is going towards the direction of sustainability, because "it comes up with different green stuff like events, lessons, programmes". More than half of the interviewed Dutch students considered that their university still had a lot to do to become sustainable: "HAN is only $40 \%$ sustainable, because they use a lot of electricity, and not necessarily from solar panels and does not eliminate plastic from the use", "escalators and lights are permanently running around the university", "water in the bathrooms does not have automatic sensors". Sustainable actions mentioned by students are presented in figure no. 4.

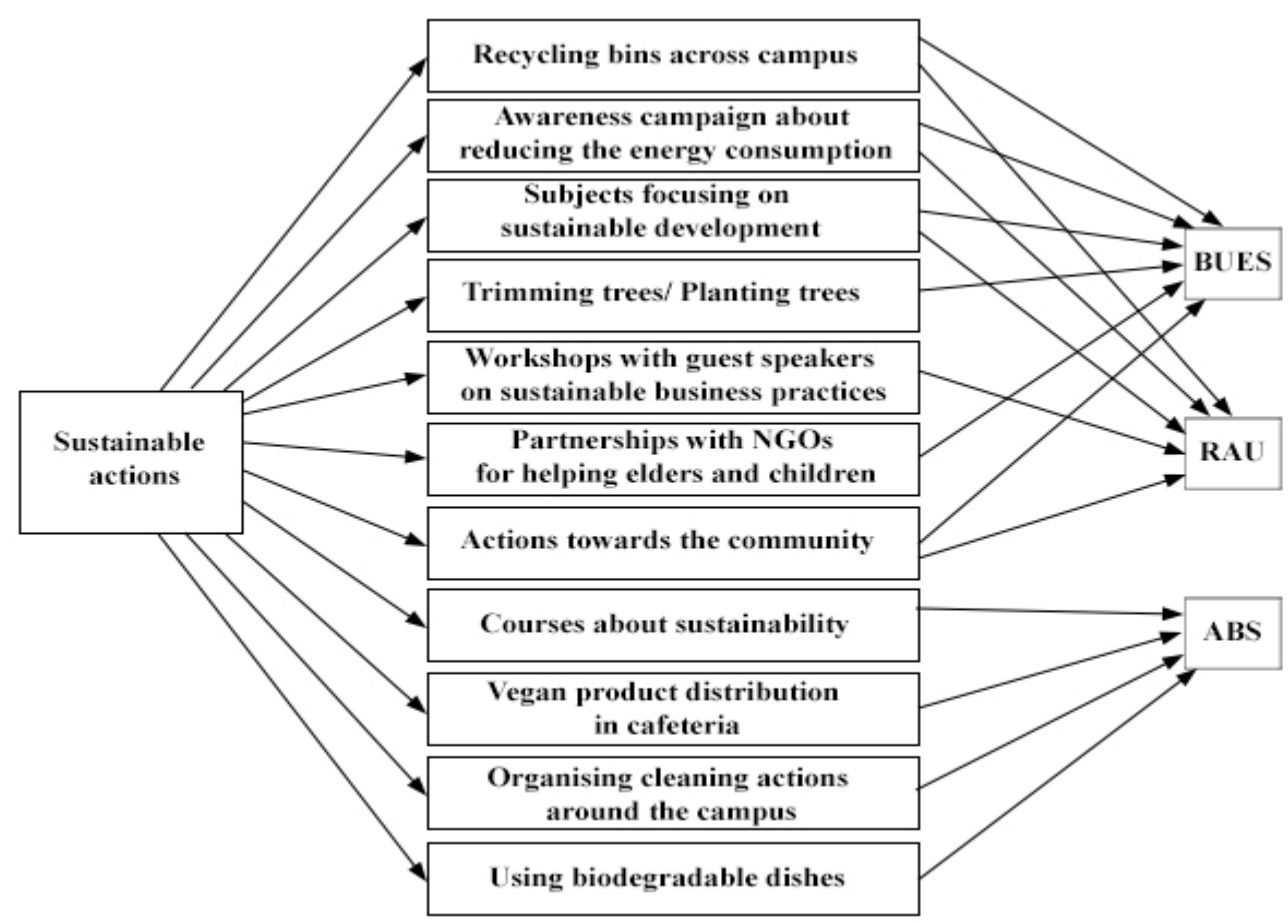

Figure no. 4: Actions that define a Sustainable University 
d) Do you consider that your university trained/educated you to behave in a sustainable way as a future employee, a future entrepreneur/ as a future business leader?

The interviewed students (both Dutch and Romanians) tended to consider themselves rather uneducated in the spirit of sustainability. "We have a clue, but..." mentioned one student from BUES. The first source for this "clue" is the sustainable education all the students mentioned they received. Most of the students (from BUES, RAU and ABS) mentioned lectures they had during their studies about sustainable development: "we discussed about sustainable development on several occasions: at the management courses, at the marketing courses, at the international business courses or business ethics courses". Secondly, students mentioned entrepreneurship education as contributing to a future sustainable behaviour (from BUES, RAU and ABS). They explained that entrepreneurship courses discussed sustainable development, from the environmental but also from the social perspectives. This might be explained by the focus on entrepreneurship of the curricula developed by business schools. Some of the Dutch students, however, mentioned that their sustainable behaviour was shaped by their internship they had during their student life. This is one of the most important aspects of our study that adds a practical value to the research. The importance of the internship, of the "learning by doing" is demonstrated once again and the universities have to be more concerned about the content and the effectiveness of the internship. Because of the higher awareness about sustainability, it is not surprisingly that half of the Dutch students considered themselves "not educated or partially educated" to act and behave in a sustainable way after graduation. It may be considered that the more aware the students are about sustainability, the more exigent they are about how they are educated to ensure the world sustainability. The Dutch students from HAN University (ABS), comparing to the Romanian students (from BUES and RAU), are more concerned about sustainability, because they did not only receive information about sustainability, they were involved in activities related to a sustainable behaviour and they were able to assess what should be done in order to improve this behaviour. A synthesis of the discussion about students' perception on their own training/education/implication in a sustainable way is presented in the figure no.5.

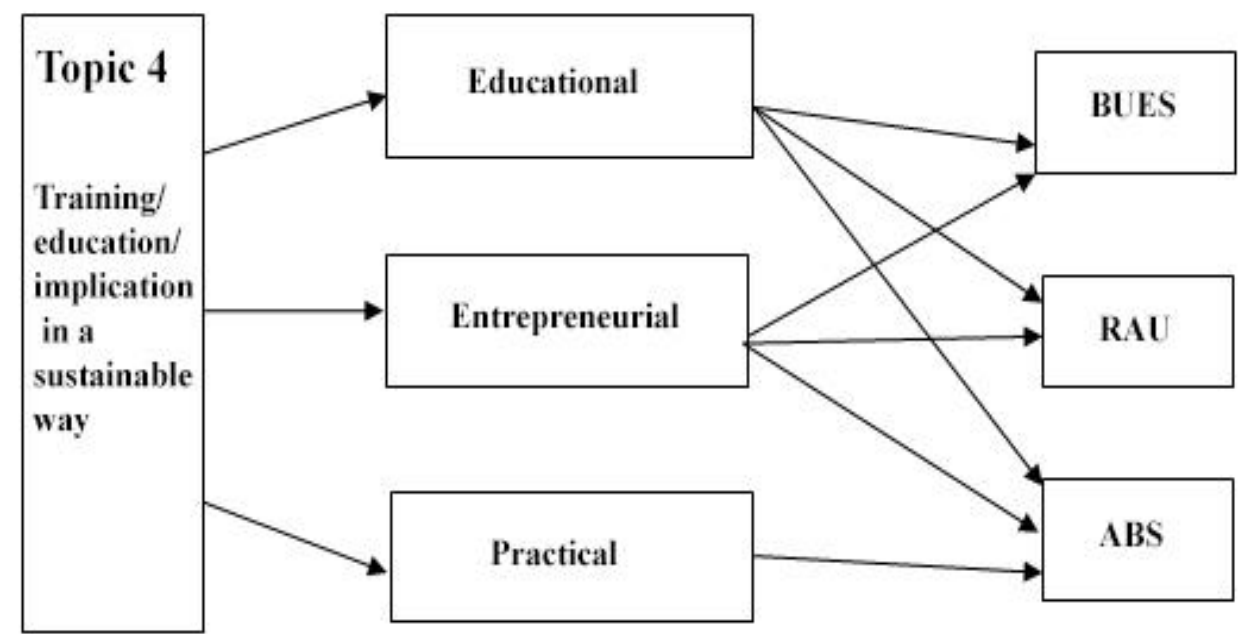

Figure no. 5: Training/education/implication in a sustainable way 


\subsection{Matrix analysis of the students' perception and secondary data research on the sustainability of universities}

This matrix (table no. 1) shows that the selected universities concentrate on the operating aspects: from this perspective, students recognize they have knowledge about sustainable development and about sustainability in general. However, this knowledge, mostly in the case of he interviewed Romanian students, does not necessarily create sustainable behaviours. Through their comments, students demand a higher cohesion among the actions universities perform in the area of sustainability: a clear focus about what sustainability means, more student involvement in the actions towards sustainability developed by universities, more practical value of the conducted research in the area of sustainability. More doesn't mean better. Sometimes students are overwhelmed by the activities performed by their universities. The universities should be proactive and should demonstrate the capacity to realize the transition from "saying" (education, research and events) to "doing" (involving, internship, reporting, communication), and, finally, to "improving" (being innovative in the area of sustainability). This will create not only a generation more aware about sustainability, but a more demanding generation who will foster universities and the society, in general, to act more responsibly and, as a consequence, more sustainably.

Table no.1 Descriptive analysis of the selected universities versus students' perception on sustainable university

\begin{tabular}{|c|c|c|c|c|c|}
\hline University & Planning & Operating & Reporting & Innovating & $\begin{array}{l}\text { Students' } \\
\text { perception }\end{array}$ \\
\hline $\begin{array}{l}\text { HAN } \\
\text { University } \\
\text { of Applied } \\
\text { Sciences } \\
\text { (ABS) }\end{array}$ & $\begin{array}{l}\text { Sustainability } \\
\text { is present in } \\
\text { the mission } \\
\text { and vison of } \\
\text { the university }\end{array}$ & $\begin{array}{l}\text { Courses and } \\
\text { programmes } \\
\text { focused on } \\
\text { sustainability } \\
\text { are present. } \\
\text { Research on } \\
\text { sustainability } \\
\text { is in place. } \\
\text { Campus } \\
\text { organisation } \\
\text { takes into } \\
\text { consideration } \\
\text { sustainable } \\
\text { principles. }\end{array}$ & $\begin{array}{l}\text { The University } \\
\text { publishes } \\
\text { yearly a report } \\
\text { that involves a } \\
\text { part devoted to } \\
\text { sustainability. } \\
\text { A specific } \\
\text { report on } \\
\text { sustainability } \\
\text { and ethics is } \\
\text { planned to be } \\
\text { delivered } \\
\text { (Arnhem } \\
\text { Business } \\
\text { School) }\end{array}$ & $\begin{array}{l}\text { University is } \\
\text { engaging in } \\
\text { HESI } \\
\text { (Higher } \\
\text { Education } \\
\text { Sustainable } \\
\text { Initiative). }\end{array}$ & $\begin{array}{l}\text { Moderate } \\
\text { awareness } \\
\text { about the } \\
\text { sustainability } \\
\text { of their } \\
\text { university } \\
\text { High } \\
\text { awareness } \\
\text { about the } \\
\text { need of } \\
\text { sustainable } \\
\text { education } \\
\text { and practice } \\
\text { Exigent } \\
\text { about how } \\
\text { university } \\
\text { should act in } \\
\text { order to } \\
\text { become more } \\
\text { sustainable }\end{array}$ \\
\hline
\end{tabular}




\begin{tabular}{|c|c|c|c|c|c|}
\hline University & Planning & Operating & Reporting & Innovating & $\begin{array}{l}\text { Students' } \\
\text { perception }\end{array}$ \\
\hline $\begin{array}{l}\text { The } \\
\text { Bucharest } \\
\text { University } \\
\text { of } \\
\text { Economic } \\
\text { Studies }\end{array}$ & $\begin{array}{l}\text { There are no } \\
\text { specific } \\
\text { mentions that } \\
\text { sustainability } \\
\text { is central to } \\
\text { the mission } \\
\text { and the vision } \\
\text { of the } \\
\text { university. } \\
\text { References } \\
\text { towards } \\
\text { sustainability } \\
\text { are present }\end{array}$ & $\begin{array}{l}\text { Sustainability } \\
\text { is present in } \\
\text { all parts of } \\
\text { the operating } \\
\text { area: courses, } \\
\text { programmes, } \\
\text { events, } \\
\text { research. } \\
\text { Campus } \\
\text { organisation } \\
\text { and } \\
\text { community } \\
\text { involvement } \\
\text { is less visible. }\end{array}$ & $\begin{array}{l}\text { The } \\
\text { communication } \\
\text { strategy of the } \\
\text { university is } \\
\text { lacking in } \\
\text { focusing on } \\
\text { sustainability. } \\
\text { No reports on } \\
\text { sustainability } \\
\text { are available. } \\
\text { No specific part } \\
\text { devoted to } \\
\text { sustainability is } \\
\text { present in the } \\
\text { reporting } \\
\text { activity of the } \\
\text { university. }\end{array}$ & $\begin{array}{l}\text { No } \\
\text { information } \\
\text { available } \\
\text { about any } \\
\text { association or } \\
\text { initiative } \\
\text { concentrated } \\
\text { on university } \\
\text { sustainability. }\end{array}$ & $\begin{array}{l}\text { Low } \\
\text { awareness } \\
\text { about } \\
\text { sustainability } \\
\text { of their } \\
\text { university } \\
\text { Moderate } \\
\text { awareness } \\
\text { about the } \\
\text { need of } \\
\text { sustainable } \\
\text { education } \\
\text { and practice } \\
\text { Low } \\
\text { awareness } \\
\text { about how } \\
\text { university } \\
\text { should act in } \\
\text { order to } \\
\text { become more } \\
\text { sustainable }\end{array}$ \\
\hline $\begin{array}{l}\text { Romanian } \\
\text { American } \\
\text { University }\end{array}$ & $\begin{array}{l}\text { There are no } \\
\text { specific } \\
\text { mentions that } \\
\text { sustainability } \\
\text { is central to } \\
\text { the mission } \\
\text { and the vision } \\
\text { of the } \\
\text { university. } \\
\text { References } \\
\text { towards } \\
\text { sustainability } \\
\text { are present }\end{array}$ & $\begin{array}{l}\text { Sustainability } \\
\text { is present in } \\
\text { all parts of } \\
\text { the operating } \\
\text { area: courses, } \\
\text { programmes, } \\
\text { events, } \\
\text { research. } \\
\text { Campus } \\
\text { organisation } \\
\text { and } \\
\text { community } \\
\text { involvement } \\
\text { is less visible. }\end{array}$ & $\begin{array}{l}\text { The } \\
\text { communication } \\
\text { strategy of the } \\
\text { university is } \\
\text { lacking in } \\
\text { focusing on } \\
\text { sustainability. } \\
\text { No reports on } \\
\text { sustainability } \\
\text { are available. } \\
\text { No specific part } \\
\text { devoted to } \\
\text { sustainability is } \\
\text { present in the } \\
\text { reporting } \\
\text { activity of the } \\
\text { university. }\end{array}$ & $\begin{array}{l}\text { No } \\
\text { information } \\
\text { available } \\
\text { about any } \\
\text { association or } \\
\text { initiative } \\
\text { concentrated } \\
\text { on university } \\
\text { sustainability. }\end{array}$ & $\begin{array}{l}\text { Low } \\
\text { awareness } \\
\text { about } \\
\text { sustainability } \\
\text { of their } \\
\text { university } \\
\text { Moderate } \\
\text { awareness } \\
\text { about the } \\
\text { need of } \\
\text { sustainable } \\
\text { education } \\
\text { and practice } \\
\text { Low } \\
\text { awareness } \\
\text { about how } \\
\text { university } \\
\text { should act in } \\
\text { order to } \\
\text { become more } \\
\text { sustainable }\end{array}$ \\
\hline
\end{tabular}

Source: Authors' own compilation based on the findings of the research 


\section{Conclusions}

Taking into account the pivotal role universities have in shaping the future behaviour of the next generations of entrepreneurs, business leaders and employees, how universities act as sustainable agents is of a crucial importance. Starting from this reality, the present research involved a comparison between three universities (one university from the Netherlands and two universities from Romania), aiming to investigate the awareness of the concept of sustainable university among the students and to identify how the students evaluate their universities in terms of sustainability. The study involved, at an initial stage, an analysis of the secondary data, based on the online information provided by universities on their websites, in order to evaluate their sustainability based on the adapted concept of the Deming spiral (planning, operationalization, reporting and innovation). In the second phase, the research involved focus groups with students from these three universities to analyse their opinion on the sustainability of their universities.

The adapted Deming spiral showed that the three analysed universities were quite well developed in the area of operating (sustainability is present in education, research, community involvement and campus organisation). Mainly education and research are well developed in all three universities. Less information is available regarding community involvement and campus organisation, especially in the case of the Romanian universities.

From the planning perspective, the Dutch university (HAN University of Applied Sciences) displays a stronger commitment towards sustainability. Romanian universities indicate sustainability not as their primary purpose, and the commitment towards sustainability appears as a consequence of the primary purposes, respective education and research. It seems that between the Dutch university and the Romanian universities, selected for this research, is not a "knowledge gap", but a "commitment gap" (Emanuel and Adams, 2011)

A clearer difference appears in the last two waves of the Deming spiral: reporting and innovating. If HAN University (ABS) may be considered a university that started an undoubted orientation towards sustainability, the Romanian universities can be appreciated as traditional universities. Neither BUES nor RAU proves to have a specific communication strategy about sustainability; they have a low (or inexistent) participation in sustainable networks (Velasquez, et al., 2006; Lozano, et al., 2013), and they do not perform proactive actions to achieve sustainability (Lukman and Glavič, 2007).

Students' perceptions follow the path revealed by the Deming spiral. The Romanian students showed a low level of awareness about university sustainability. A consistently larger proportion of the Dutch respondents expressed a larger awareness about sustainability, in general, and sustainable university in particular. Sustainability is associated mainly with environmental aspects (a conclusion that is consistent with the literature) and less associated with social (community involvement) and economic dimensions. An interesting conclusion is related to Entrepreneurship education that, according to the interviewed students' opinion, seems to contribute to knowledge about sustainability.

Respondents' were somehow on the same length in their self-assessed behaviour about sustainability. They did not see themselves enough prepared to act as sustainable business people and suggested that their university should do more in this sense. Universities should have a better communication strategy regarding their sustainability and a clearer focus on how sustainability should be transformed from knowledge to behaviour. Learning by doing seems 
to be a good practice: students should be directly involved in acting sustainably, through internship (which should be more effective), by participating in the research projects, or other practices. Romanian universities may adopt a practice developed by ABS in building "global citizenship" for students through internship (three cultures approach). Three cultures approach is a concept the ABS implemented for strengthening their global citizenship. This approach means that you, as a student to ABS have to be exposed to three cultures. If you are a Dutch student studying at ABS you are exposed to your culture, then you have to study for at least a semester in another country (exposure to culture no 2) and to have an internship to a company that is not a Dutch one or is not coming from the country you have studied for a semester (discussion with the Dean of the ABS, November 2019).

Another good practice in order to strengthen the awareness about sustainability, in general, is to introduce sustainability/responsibility as a compulsory part of any report. This may help students to anticipate not only financial or economic risks, for example, of any action they will propose, but to assess it from the environmental and social perspectives.

This study has to be interpreted in a qualitative way. The research findings have value mainly from an exploratory perspective and the results cannot be generalised for all students from the investigated universities or for all universities from the Netherlands and Romania. However, the study conclusions are important for universities decision makers, as well as for progress of the research in the field. The decision makers from universities can start from these results to create or to improve strategies aimed at building sustainable university endeavours, and, even more importantly, to start assessing how such strategies are perceived by students and other stakeholders. By all means, any strategy has to be shared with stakeholders, internal and external. From academic perspective, this research adds to the existing empirical studies, contributing to theoretical consolidation of the concept of sustainable university. Comparative perspective proposed by this study shows the importance of the context on the way university sustainability is perceived. Moreover, this study can be a suitable starting point for a future quantitative research, based on representative samples, to measure not only students' perception on university sustainability, but other key stakeholders' one, such as academics, administrative staff or business representatives.

\section{Acknowledgement}

This research was possible due to a FSS Shanghai grant received by Rodica Milena Zaharia in 2019 from The Bucharest University of Economic Studies for a stage at Arnhem Business School.

\section{References}

Adams, R., Martin, S. and Boom, K., 2018. University culture and sustainability: Designing and implementing an enabling framework. Journal of Cleaner Production, 171, pp.434-445.

Amaral, L.P., Martins, N. and Gouveia, J.B., 2015. Quest for a sustainable university: a review. International Journal of Sustainability in Higher Education, 16(2), pp.155-172. 
Assembly, U. G., 1987. Report of the world commission on environment and development: Our common future. United Nations. [online] Available at: $<$ https://sustainabledevelopment.un.org/content/documents/5987our-commonfuture.pdf $>$ [Accessed 30 October 2019].

ASE, 2019. Raportul Anual al Rectorului Academiei de Studii Economice din București privind Starea Universității pentru Anul 2018. [online] Available at: <https://www.ase.ro/2013_files/despre_ase/conducere/pdf/Raport_rector_2018.pdf> [Accesat 23 November 2019].

ASE, 2014. Strategia ASE. [online] Available at: <https://www.ase.ro/2013_files/ despre_ase/legislatie/strategia14-20/Strategia\%20ASE\%202014-2020.pdf> [Accessed 25 October 2019].

ASE, 2013. Charta ASE. [online] Available at: <https://www.ase.ro/2013_files_en/ despre_ase/pdf/Carta_ASE_2016_EN.pdf.> [Accessed 23 October 2019].

Björk, P. and Kauppinen-Räisänen, H., 2012. A netnographic examination of travelers' online discussions of risks. Tourism Management Perspectives, 2, pp.65-71.

Brewis, J., 2014. The Ethics of Researching Friends: On Convenience Sampling in Qualitative Management and Organization Studies. British Journal of Management, 25(4) pp.849-862.

Chiodo, E., 2013. Sustainable Development in Higher Education in Europe: Good Practices Compendium. Homeless Book.

Comm, C.L. and Mathaisel, D.F., 2003. Less is more: a framework for a sustainable university. International Journal of Sustainability in Higher Education, 4(4), pp.314-323.

Dabija, D., Postelnicu, C., Dinu, V. and Mihăilă, A., 2017. Stakeholders’ perception of sustainability orientation within a major Romanian University. International Journal of Sustainability in Higher Education, 18(4), pp.533-553.

EFEMED, 2019. About us. [online] Available at: <https://efmdglobal.org/accreditations/ business-schools/epas/> [Accessed 10 October 2019].

Emanuel, R. and Adams, J.N., 2011. College students' perceptions of campus sustainability. International Journal of Sustainability in Higher Education, 12(1), pp.79-92.

HAN University of Applied Sciences, 2018. Bestuursverslag. [pdf] Available at: <https://www.han.nl/over-de-han/organisatie/jaarverslag-enverantwoording/han_bestuursverslag_2018_def.pdf.> [Accessedat 23 November 2019].

HAN University of Applied Sciences, 2019. Institutional Plan 2016-2020. [online] Available at: <https://www.han.nl/international/english/about-han/mission-and-values/> [Accessed 1 October 2019].

Kagawa, F., 2007. Dissonance in students' perceptions of sustainable development and sustainability: Implications for curriculum change. International Journal of Sustainability in Higher Education, 8(3), pp.317-338.

Kivunja, C., 2015. Innovative methodologies for 21st century learning, teaching and assessment: A convenience sampling investigation into the use of social media technologies in higher education. International Journal of Higher Education, 4(2), pp.1-26.

Li, P., Parsa, S., Tang, G. and Xiao, J. Z., 2012. Is there an expectations gap in the roles of independent directors? An explorative study of listed Chinese companies. British Journal of Management, 23, pp.206-222. 
Lozano, R., Lukman, R., Lozano, F.J., Huisingh, D. and Lambrechts, W., 2013. Declarations for sustainability in higher education: becoming better leaders, through addressing the university system. Journal of Cleaner Production, 48, pp.10-19.

Lukman, R. and Glavič, P., 2007. What are the key elements of a sustainable university?. Clean Technologies and Environmental Policy, 9(2), pp.103-114.

Martin, J., 2012. The sustainable university: Green goals and new challenges for higher education leaders. JHU Press.

Nejati, M. and Nejati, M., 2013. Assessment of sustainable university factors from the perspective of university students. Journal of Cleaner Production, 48, pp.101-107.

Ríos-Martín, M. Á., Folgado-Fernández, J. A., Palos-Sánchez, P.R. and Castejón-Jiménez, P., 2020. The Impact of the Environmental Quality of Online Feedback and Satisfaction When Exploring the Critical Factors for Luxury Hotels. Sustainability, 12, pp.299.

Sonetti, G., Lombardi, P. and Chelleri, L., 2016. True green and sustainable university campuses? Toward a clusters approach. Sustainability, 8(1), pp.83.

Sterling, S., Maxey, L. and Luna, H. (Eds.), 2013. The sustainable university: Progress and prospects. Routledge.

UNESCO, 2002. Education for sustainability: from Rio to Johannesburg, lessons learnt from a decade of commitment. [online] Available at: <https://unesdoc.unesco.org/ark:/ 48223/pf0000127100> [Accessed 23 October 2019].

UN, 2019. Higher Education Sustainable Initiative. [online] Available at: $<$ https://sustainabledevelopment.un.org/sdinaction/hesi> [Accessed 23 October 2019].

URA, 2019. Raportul de Evaluare Internă privind Asigurarea Calității în Universitatea Româno-Americană în anul 2018. Program Operațional de Asigurare a Calității pentru anul 2019. [online] Available at: <http://web.rau.ro/mydocuments/dac/ Raport\%20calitate\%20-\%202018.pdf> [Accessed 30 November 2019].

Van Weenen, H., 2000. Towards a vision of a sustainable university. International Journal of Sustainability in Higher Education, 1(1), pp.20-34.

Velazquez, L., Munguia, N., Platt, A. and Taddei, J., 2006. Sustainable university: what can be the matter? Journal of Cleaner Production, 14(9-11), pp.810-819.

Yuan, X. and Zuo, J., 2013. A critical assessment of the Higher Education for Sustainable Development from students' perspectives - a Chinese study. Journal of Cleaner Production, 48, pp.108-115.

Zaharia, R. and Zaharia, R.M., 2017. Qualitative Research Methods: how to Ask and Whom to Ask? A Comparison between Focus Group and In-depth Interviews, International E-Conference: Enterprises in The Global Economy Edited by: Vancea, DPC; Zaharia, RM, pp.144-149. [online] Available at: <https://www.filodiritto.com/ qualitative-research-methods-how-ask-and-whom-ask-comparison-between-focusgroup-and-depth-interviews1> [Accessed 1 March 2020].

Zeegers, Y. and Clark, I.F., 2014. Students' perceptions of education for sustainable development. International Journal of Sustainability in Higher Education, 15(2), pp.242-253. 